\title{
Soil Organic Carbon Sequestration in Rice-Wheat System under Conservation and Conventional Agriculture in Western Chitwan, Nepal
}

\author{
Madhab Paudel ${ }^{1, *}$, Shrawan Kumar Sah ${ }^{2}$, Andrew McDonald ${ }^{3}$, Narendra Kumar Chaudhary ${ }^{4}$ \\ ${ }^{1}$ Agro Enterprise Centre, Federation of Nepalese Chambers of Commerce and Industries, Dadeldhura, Nepal \\ ${ }^{2}$ Department of Agronomy, Agriculture and Forestry University, Rampur, Chitwan, Nepal \\ ${ }^{3}$ CIMMYT, South Asia Regional Office, Kathmandu, Nepal \\ ${ }^{4}$ Institute of Agriculture and Animal Science, Tribhuvan University, Kathmandu, Nepal \\ *Corresponding author: paudel.madhab@gmail.com
}

Received October 11, 2014; Revised November 12, 2014; Accepted December 28, 2014

\begin{abstract}
Soil organic carbon plays the crucial role in maintaining soil quality. The impact and rate of SOC sequestration in CA and conventional agriculture is still in investigation in this environment. A field experiment was initiated in 2011/12 and continued up to 2012/13 to compare the organic carbon buildup in the soil due to conservation and conventional agriculture. The soil organic carbon data represents the cumulative after five crop cycle. The treatments consisted conventionally tilled direct seeded rice followed by zero tilled wheat, conventionally tilled transplanted rice followed by conventionally tilled wheat, zero tilled direct seeded rice followed by zero tilled direct seeded wheat without residue retention, zero tilled direct seeded rice followed by direct seeded wheat with residue retention, permanent raised bed of rice followed by wheat without residue retention and permanent raised bed of rice followed by wheat with residue retention in randomized complete block design with three replications. About $4 \mathrm{t}$ ha- 1 of standing rice and wheat crop and about $70 \%$ residue of moongbean was retained for succeeding crop in retained treatments. Soil samples from each treatments were collected from two soil depths (0-20 and 20$40 \mathrm{~cm}$ ) and analyzed. Result showed that, soil organic carbon buildup was affected significantly by tillage and residue level in upper depth of 0-20 cm but not in lower depth of 20-40 cm. Higher SOC content of $19.44 \mathrm{~g} \mathrm{~kg}^{-1}$ of soil was found in zero tilled residue retained plots followed by $18.53 \mathrm{~g} \mathrm{~kg}^{-1}$ in permanently raised bed with residue retained plots. Whereas, the lowest level of SOC content of $15.86 \mathrm{~g} \mathrm{~kg}^{-1}$ of soil were found in puddled transplanted rice followed by wheat planted under conventionally tilled plots. Zero tilled residue retained plots sequestrated 0.91 $\mathrm{g} \mathrm{kg}^{-1} \mathrm{yr}^{-1}$ SOC in the year 2012/13 which was 22.63\% higher over the conventionally tilled residue removed plots after five seasons of experimentation. Therefore, CA in rice-wheat system can help directly in building-up of soil organic carbon and improve the fertility status of soil.
\end{abstract}

Keywords: soil organic carbon, CA, rice-wheat system, residue retention

Cite This Article: Madhab Paudel, Shrawan Kumar Sah, Andrew McDonald, and Narendra Kumar Chaudhary, "Soil Organic Carbon Sequestration in Rice-Wheat System under Conservation and Conventional Agriculture in Western Chitwan, Nepal.” World Journal of Agricultural Research, vol. 2, no. 6A (2014): 1-5. doi: 10.12691/wjar-2-6A-1.

\section{Introduction}

Rice and wheat cropping system is very intensive (Tripathi, 2010) and more exhaustive (Beri et al., 2002; Sharma and Behera 2011). Production and productivity of the system is very low (Regmi et al., 2003). Declining or stagnant yield and impact on environment are major well known problems of cropping system (Khanal et al., 2012).

Soil organic carbon is the fraction of organic matter; the decomposed plant and animal materials including microbial population. It is directly associated with nutrient availability, soil physical properties, and biological soil health and buffer actions over various toxic substances. Soil carbon level determined to the abundance of nutrient and equilibrium of various nutrient elements (Bot and Benites, 2005). With the increase in the concentration of soil organic carbon, yield of the crop is increased directly especially in sandy loam soil (Rattan and Datta, 2011). The major cause of yield decline in this system is nutrient imbalance, which is associated with soil organic matter, declining over time where intensive cropping has been experienced (Ladha et al., 2000).

The equilibrium level of SOC in the soil is the function of climate, soil and nature of vegetation (Rattan and Datta, 2011). The carbon content was decreased up to by $15 \%$ per unit increase in $\mathrm{pH}$, increase by $1 \%$ per percent increase in clay content and decreased up to by $0.3 \%$ per percent increase in slope (Bronson et al., 1997). It is the function of residue and roots (Bot and Benites, 2005). 
Residue retention helps to maintain good soil structure, increase in biological activity in soil and supply important nutrient elements (Watson et al., 2002). In general, rice residue after grain harvest has been used for animal feed, a valuable animal feed and wheat straw has been burned for the facilitation of summer ploughing. The rice straw feeding culture is more in case of small holder farmers especially. Farmers burn straw of rice-wheat field each year to facilitate the crop planting (Gupta and Seth, 2007).

Increasing level of soil organic carbon into soil not only enhance soil quality but also help to reduce GHGs emission; lowers climate change (Chan, 2008). About 8\% of global energy used is used by agriculture in various farm operations including tillage, irrigation, harvesting and threshing; the rate has increasing (Tandon and Singh, 2009). Agriculture contributes about $20 \%$ of increase of annual GHGs emission by anthropogenic activity (Aydinalp and Cresser, 2008). Emission of carbondioxide $\left(\mathrm{CO}_{2}\right)$, methane $\left(\mathrm{CH}_{4}\right)$, and nitrous oxide $\left(\mathrm{N}_{2} \mathrm{O}\right)$ has major role in warming potential and this is mainly associated with rice based cropping system (Kumar and Ladha, 2011).

Emission of $\mathrm{CO}_{2}$ and $\mathrm{NOx}$ can be decreased by adopting reduced tillage and residue management (Lumpkin and Sayre, 2009) and nitrous oxide gas emission is greatly reduced in residue retained rice field (Bhattacharyya et al. 2012). Grace et al. (2003) reported the reduction of methane gas emission by adopting water and fertilizer management with selection of cultivars emits less methane. Singh and Sharma, (2005) showed up to 70 $\mathrm{kg} \mathrm{ha}{ }^{-1} \mathrm{yr}^{-1} \quad \mathrm{CO}_{2}$ emission from rice-wheat field to environment has reduced by adopting zero tillage in place of conventional tillage.

Conservation agriculture is holistic approach of crop production (Venkateswarlu et al., 2009) and viable alternative to current crop production system which is sustainable, technically successful and economic (Derpsch and Friedrich, 2009b). CA technique provides equal or more productivity, improve soil health and higher farm profitability in sustainable way in comparison to conventional practice (Jat et al., 2009). Former researchers in this reason Regmi et al. (2003), Ghimere et al. (2012) suggested the further researches to conclude about SOC sequestration in rice-wheat system under conventional and conservation agriculture. Therefore, with the aforementioned situation, aspects and needs, research had conducted with the objective to find out the SOC sequestration in the rice-wheat system under conventional and conservation agriculture.

\section{Materials and methods}

\subsection{Experimental site and Cropping History}

The experiment was conducted on research farm of Institute of Agriculture and Animal science (IAAS) Rampur, Chitwan. The trial was initiated during 2011 and treatments setup was started since May, 2011. Two crops, rice and wheat were planted during 2011/12. The fallow period between wheat and rice was utilized by growing moongbean other than conventional plots. 30\% residue of rice and wheat was retained on some of the CA plots. In the experiment of 2012/13, 75\% of mongbean residue on rice and $30 \%$ of Rice residue on wheat experiment was retained on residue retained treatments. Therefore, data of soil organic carbon increase denotes five crop cycles.

The mean maximum temperature during the experimental period ranged from $21^{\circ} \mathrm{C}$ in January, 2013 to $35.1^{\circ} \mathrm{C}$ in June, 2012. The mean minimum temperature during the cropping period ranged from $1.83^{\circ} \mathrm{C}$ in January, 2013 to $28^{\circ} \mathrm{C}$ in August, 2012. No rainfall was recorded during November and December, 2012 and February, 2013. The highest rainfall during the experimental period was $485.5 \mathrm{~mm}$ in July, 2012. The total rainfall during the rice season was $1015.35 \mathrm{~mm}$ and maximum (485.55 mm) occurred during July. The average relative humidity during the experimental period ranged from $83.6 \%$ in April, 2012 to 99.6\% in December, 2012.

The experiment was laid out in a randomized complete block design (RCBD) with three replications and 6 treatments. The net plot size was $(6 \mathrm{mx} 6 \mathrm{~m}) 36 \mathrm{~m}^{2}$. Treatments were Conventional tilled dry direct seed Rice followed by Zero tilled wheat (CTDSR+ ZTW), Transplanted rice followed by conventional tilled wheat (TPR+CTW), Zero tilled rice followed by wheat without residue retention (ZTR-ZTW+RH), Zero tilled rice followed by wheat with residue retention (ZTR$\mathrm{ZTW}+\mathrm{RR}$ ), permanent raised bed rice followed by wheat without residue retention $(\mathrm{BPR}-\mathrm{BPW}+\mathrm{RH})$ and permanent raised bed rice followed by wheat without residue retention with residue retention (BPR-BPW+RR). Seeds were sown with $20 \mathrm{~cm}$ spacing in continuous row in the treatments of direct seeded (conventional, zero and bed planting) rice and wheat but puddled transplanted rice, three seedlings per hill were transplanted in 20 x $20 \mathrm{~cm}^{2}$ geometry. In bed planting, two continuous rows of rice and wheat seeds per bed were seeded directly on each bed. Manually operated locally made furrow opener was used for direct seeded rice while, manual transplanting was done in puddled transplanted treatment.

Composite samples were collected randomly from five different spots in each plot before and after each crop planted at two different depths of 0-20 cm and 20-40 cm using screw auger to record the initial and final physiochemical properties of the research field. The samples were shade/air dried, grounded and sieved in 2 mm sized sieve and then subjected to physical and chemical analysis. The sample taken was also used to analysis of texture, nitrogen, phosphorous, potash and $\mathrm{pH}$ for descriptive purpose.

Soil organic matter determination by Loss on Ignition method is considered as standard method since long time having relatively more recovery efficiency. Soil sample from carefully weighed $1 \mathrm{~g}$ sample was heated to $600^{\circ} \mathrm{C}$ for 4 hour. The weighing balance was $0.001 \mathrm{~g}$ setting. Reduced weight from heated sample was soil organic matter. Organic matter contains 58\% soil organic carbon (Schumacher, 2002). Hence, in this way soil organic carbon from all samples was calculated. The soil samples were subjected to comparative soil organic carbon analysis by Walkley-Black procedure for the verification of LOI analysis.

\section{Results}

\subsection{Physicochemical Properties of Soil}


The soil of the experimental field was sandy loam in texture and acidic in reaction. It contains medium rating organic matter on upper $20 \mathrm{~cm}$ depth and low in lower depth of $20-40 \mathrm{~cm}$. The level of Nitrogen was medium but phosphorous and potash was low in rating.

\subsection{Soil Organic Carbon Content of the Field (g kg-1 Soil)}

The status of soil organic carbon at two different depths was analyzed (Table 1) to accomplish the annual soil organic carbon deposition under various treatments of the continuous trial of rice-wheat system. The mean soil organic carbon content at the upper $0-20 \mathrm{~cm}$ depth was $17.25 \mathrm{~g} \mathrm{~kg}^{-1}$ soil before rice season at 2012 and $17.58 \mathrm{~g}$ $\mathrm{kg}^{-1}$ soil after wheat season at 2013. The soil organic carbon at upper $0-20 \mathrm{~cm}$ depth was significantly influenced by conventional and conservation agricultural practices. But the soil of lower depth, 20-40 cm, organic carbon content was relatively lower and statistically similar among the treatments.

At every sampling, zero tilled residue retained treatment contained significantly higher amount of soil carbon followed by permanent raised bed residue retained treatment than other treatments at $0-20 \mathrm{~cm}$ depth. Before rice season, ZTR-ZTW+RR contained higher soil carbon (18.53 g kg-1 soil), statistically similar with BPR$\mathrm{BPW}+\mathrm{RR}$ (18.23 $\mathrm{g} \mathrm{kg}^{-1}$ soil). The trend was similar till the end of the experiment. Similarly after wheat season, ZTRZTW+RR contained higher (19.44 $\mathrm{g} \mathrm{kg}^{-1}$ ) soil carbon followed by permanent BPR-BPW+RR (18.96 $\left.\mathrm{g} \mathrm{kg}^{-1}\right)$. The soil organic carbon content was significantly lowest in TPR-CTW. It was $15.86 \mathrm{~g} \mathrm{Kg}^{-1}$ of soil before rice season which became $15.85 \mathrm{~g} \mathrm{Kg}^{-1}$ of soil after wheat season. It was statistically similar to all other treatments except ZTR-ZTW+RR and BPR-BPW+RR.

Table 1. Soil organic carbon content as affected by conservation and conventional agricultural practice of continuous rice-wheat trial at Rampur soil, 2012/2013

\begin{tabular}{|c|c|c|c|c|}
\hline Treatments & $\begin{array}{c}\text { Before rice season } \\
0-20 \mathrm{~cm} \\
\end{array}$ & $\begin{array}{c}\text { After wheat season } \\
0-20 \mathrm{~cm} \\
\end{array}$ & $\begin{array}{c}\text { Before rice season } \\
20-40 \mathrm{~cm} \\
\end{array}$ & $\begin{array}{c}\text { After wheat season } \\
20-40 \mathrm{~cm}\end{array}$ \\
\hline CTDSR-ZTW & $16.62^{\mathrm{bc}}$ & $16.76^{\mathrm{b}}$ & 12.25 & 12.33 \\
\hline TRP-CTW & $15.86^{\mathrm{c}}$ & $15.85^{\mathrm{b}}$ & 12.2 & 12.12 \\
\hline ZTR-ZTW+RR & $18.53^{\mathrm{a}}$ & $19.44^{\mathrm{a}}$ & 12.91 & 13.03 \\
\hline ZTR-ZTW+RH & $17.62^{\mathrm{abc}}$ & $17.69^{\mathrm{ab}}$ & 12.62 & 12.75 \\
\hline BPR-BPW+RH & $16.63^{\mathrm{bc}}$ & $16.78^{\mathrm{b}}$ & 13.00 & 13.02 \\
\hline BPR-BPW+RR & $18.23^{\mathrm{ab}}$ & $18.96^{\mathrm{a}}$ & 12.52 & 12.75 \\
\hline Grand mean & 17.25 & 17.58 & 12.58 & 12.67 \\
\hline LSD (0.05) & 1.77 & 1.75 & NS & NS \\
\hline $\operatorname{SEm}( \pm)$ & 0.56 & 0.56 & 0.87 & 0.80 \\
\hline CV (\%) & 5.63 & 5.47 & 11.91 & 11.00 \\
\hline
\end{tabular}

Treatment means followed by common letter(s) in the column are not significantly different among each other based on DMRT at 0.05 . NS= non significant. CTDSR + ZTW= Conventional tilled dry direct seed Rice followed by Zero tilled wheat. TPR+CTDSW= Transplanted rice followed by conventional tilled wheat. ZTR-ZTW $+\mathrm{RH}=$ Zero tilled rice followed by wheat without residue retention. ZTR-ZTW+RR= Zero tilled rice followed by wheat with residue retention. $\mathrm{BPR}-\mathrm{BPW}+\mathrm{RH}=$ permanent raised bed rice followed by wheat without residue retention. $\mathrm{BPR}-\mathrm{BPW}+\mathrm{RR}=$ permanent raised bed rice followed by wheat without residue retention with residue retention

\subsection{Annual Change in Soil Organic Carbon $\left(\mathrm{g} \mathrm{kg}^{-1} \mathrm{yr}^{-1}\right.$ Soil)}

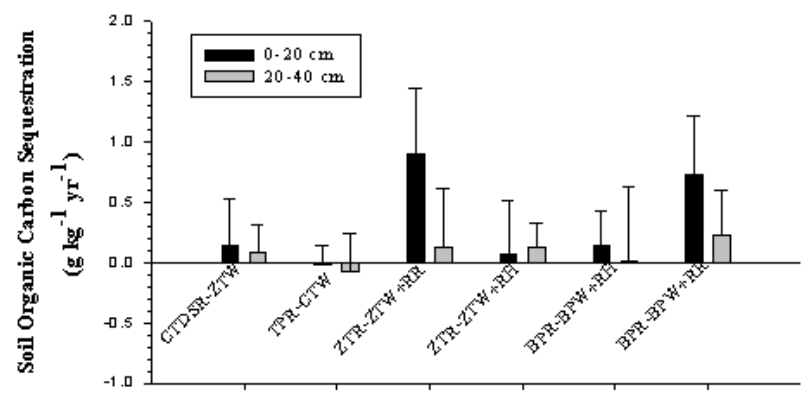

Figure 1. Change in soil organic carbon as influenced by conservation and conventional practice at Rampur, Chitwan, Nepal, 2012/13. CTDSR + ZTW = Conventional tilled dry direct seed Rice followed by Zero tilled wheat. TPR+CTDSW= Transplanted rice followed by conventional tilled wheat. ZTR-ZTW+RH= Zero tilled rice followed by wheat without residue retention. $\mathrm{ZTR}-\mathrm{ZTW}+\mathrm{RR}=\mathrm{Zero}$ tilled rice followed by wheat with residue retention. BPR-BPW $+\mathrm{RH}=$ permanent raised bed rice followed by wheat without residue retention. BPR$\mathrm{BPW}+\mathrm{RR}=$ permanent raised bed rice followed by wheat without residue retention with residue retention
Residue management and tillage clearly showed the change in soil organic (Figure 2). ZTR-ZTW+RR had higher increase in soil carbon (0.91 $\mathrm{g} \mathrm{kg}^{-1} \mathrm{yr}^{-1}$ soil) followed by BPR-BPW+RR (0.73 $\mathrm{g} \mathrm{kg}^{-1} \mathrm{yr}^{-1}$ soil) on upper depth $0-20 \mathrm{~cm}$. During experiment higher organic carbon increase in BPR-BPW+RR among the treatments in lower depth $20-40 \mathrm{~cm}$ but effect was very insignificant. Carbon content was decreased in TPR-CTW for both depths.

\subsection{Comparison of Soil Carbon Content among the Treatments}

Soil organic carbon content over TPR-CTW of the field after five crop cycle is depicted on figure 3 and presented on appendix 4. Upper depth had significantly different soil organic carbon change but lower depth was not. Highest soil organic carbon change (122.63\%) was found in ZTRZTW+RR plots followed by BPR-BPW+RR plots (111.61\%). The use of ZTR-ZTW+RR and BPR$\mathrm{BPW}+\mathrm{RR}$ for five crop cycle increased soil organic carbon by $22.63 \%$ and $11.61 \%$ more than that of TPRZTW respectively. These treatments were statistically similar and significantly higher from all other treatments except ZTR-ZTW+RH. 
Significant contrast was observed in conventional versus zero tillage and residue retention versus residue harvested practices while there was no significant difference in between zero tillage versus bed planting.
More carbon was observed in zero tillage and residue retention practice over alternative practices after five crop cycles.
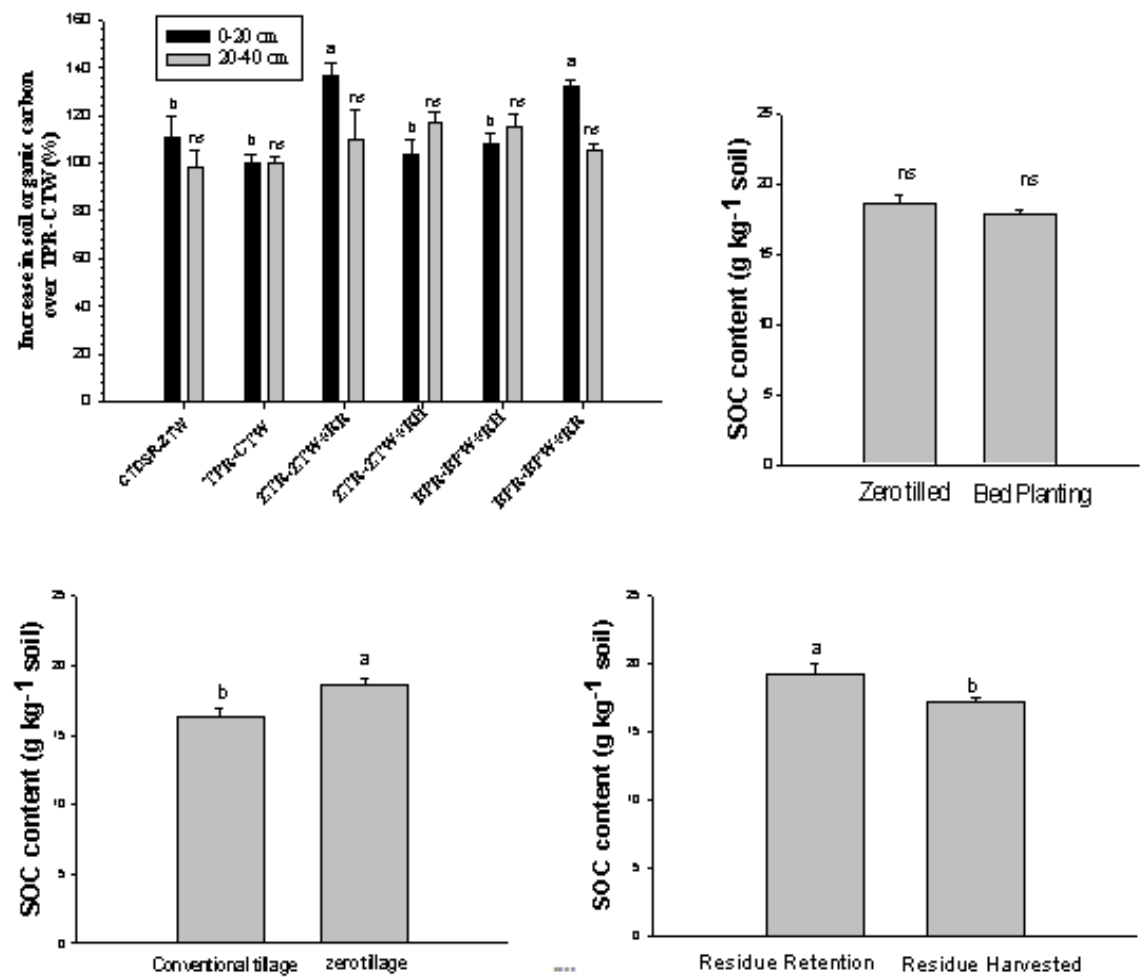

Figure 2. Increase in soil organic carbon (\%) assuming $100 \%$ for TPR followed by conventional tilled wheat influenced by conservation and conventional practice and contrast of upper depths between different practices at Rampur, Chitwan Nepal from 2011/12-2012/13. Treatment means followed by common letter(s) in the column are not significantly different among each other based on DMRT at 0.05 . NS= non significant. CTDSR + ZTW= Conventional tilled dry direct seed Rice followed by Zero tilled wheat. TPR+CTDSW= Transplanted rice followed by conventional tilled wheat. $\mathrm{ZTR}-\mathrm{ZTW}+\mathrm{RH}=$ Zero tilled rice followed by wheat without residue retention. ZTR-ZTW+RR= Zero tilled rice followed by wheat with residue retention. $\mathrm{BPR}-\mathrm{BPW}+\mathrm{RH}=$ permanent raised bed rice followed by wheat without residue retention. $\mathrm{BPR}-\mathrm{BPW}+\mathrm{RR}=$ permanent raised bed rice followed by wheat without residue retention with residue retention

\section{Discussion}

Tillage, residue management and establishment method affects carbon pool of the soil in this cropping system. In this cropping system, more increase in carbon content of soil in zero tilled residue retained plots. The percentage increment was smaller (22\% more than CT) than findings (64.6\% more than CT) of Calegari et al. (2008). Higher soil organic carbon content in residue retention could be attributed to more annual nutrient recycling in respective treatments and decreased intensity of mineralization (Kaisi and yin, 2005). Carbon input in the form of crop residue had primary factor for stabilization of soil carbon (Singh, 2011; Chivenge et al., 2007). The microbial activity was found more on residue retained plots (Mandal et al., 2004) so that soil organic carbon level increased with the residue retention (Duiker and Lal, 1999). It might also be associated to less emission of soil carbon in the form of GHGs.

Less carbon sequestration in bed planting than zero tillage in same level of residue retention in this cropping system might be due to earlier dryness, less microbial population and less decomposition in bed during wheat season. The variation of soil organic carbon sequestration also depends on difference in microbial populace, moisture and temperature fluctuation (Govaerts et al., 2009). Residue retention and tillage has key role in soil carbon conservation (Duiker and Lal, 1999; Anyanzwa et al., 2010; Du et al., 2009; Corsi et al., 2012).

Conventional methods of crop establishment and residue harvested treatments add no more carbon which might be ascribed due to continuous nutrient removal from the plot. But, the level of soil organic carbon was not much decreased in conventional or residue harvested plots also as suggested by various literatures (Anyanzwa et al., 2010; Ghosh et al., 2010), it was found as similar to initial level and sometime slightly increased. This might be due to initial low carbon content in soil and maintaining by roots (Du et al., 2009). Lack of nutrient recycling is considered to be major cause of declining soil carbon in lower depth of conventional planting (Ram et al., 2005).

\section{Conclusion}

The results obtained from the investigation indicate that conservation agriculture have the ability to add soil organic carbon. Residue retention and no-tillage can facilitate soil carbon buildup. The effective SOC sequestration in upper depth $(0-20 \mathrm{~cm})$ is due to continuous nutrient recycling as crop residue in conservation agriculture. Less carbon content and changed in conventional methods of establishment likely due to continuous losses of carbon during tillage and no recycle of carbon via residue. But, the effect on lower depth (20- 
$40 \mathrm{~cm}$ ) is insignificant in conservation agriculture also. Only two years of research might be very short period to conclude about soil organic carbon sequestration. Therefore, it needs long term study about SOC sequestration using various types of crops in different soil types and climate. Study using different rates of residue management is also essential in this region.

\section{References}

[1] Anyanzwa, H., Okalebo, J. R., Othleno C.O., Bationo, A., Waswa, B. S. \& Kihara, J. 2010. Effect of conservation tillage, crop residue and cropping systems on changes on soil organic matter and maize-legume production: A case study in Teso district. Nutr. Cycl. Agroecosyst, 88, 39-47.

[2] Beri, V., Sindhu, B. S., Bahl, G. S. \& Bhat, A. K. 1995. Nitrogen and phosphorus transformation as affected by crop residue management practices and their influence on crop yield. Soil Use Manage, 11, 51-54.

[3] Bhattacharyya, P., Roy, K. S., Neogi, S., Adhya, T. K. Rao, K. S. \& Manna, M. C. 2012. Effects of rice straw and nitrogen fertilization on greenhouse gas emissions and carbon storage in tropical flooded soil planted with rice. Soil and Tillage Research, 124, 119-130.

[4] Bot, A. \& Benites J. 2005. The importance of soil organic matter key to drought-resistant soil and sustained crop production. FAO soils bulletin. 80p.

[5] Bronson, K. F., Cassman, K. G., Wassmann, R., Olk, D. C., Noordwijk, M. V. \& Garrity, D. P. 1998. Soil carbon dynamics in different cropping systems in principal ecoregions of Asia. In: R. Lal, J.M. Kimble, R. F. Follett and B. A. Stewart (eds). Management of carbon sequestration in soil. Advances in soil science (pp. 35-57). CRC Press, New York.

[6] Calegari, A., Hargrove, W. L., Rheinheimer, D. D., Ralisch, R., Tessier, D., Tourdonnet, S. \& Guimaraes, M. F. 2008. Impact of long-term no-tillage and cropping sustem management on soil organic carbon in an Oxisol: A model for sustainability. Agronomy Journal, 100 (4), 1013-1019.

[7] Chivenge, P. P., Murwira, H. K., Giller, K. E., Mapfumo, P. \& Six, J. 2007. Long-term impact of reduced tillage and residue management on soil carbon stabilization: Implications for conservation agriculture on contrasting soils. Soil \& Tillage Research, 94, 328-337.

[8] Corsi, S., Friedrich, T., Kassam, A., Pisante, M., \& Sa, J. D. M. 2012. Soil organic carbon accumulation and greenhouse gas emission reductions from conservation agriculture: A literature review. Integrated Crop Management, Vol. 16.

[9] Derpsch, R. \& Friedrich, T. 2009. Global overview of conservation agriculture adoption. Lead papers, $4^{\text {th }}$ world congress on conservation agriculture. 429-438. 4-7 February 2009, New Delhi, India.

[10] Du, Z., Liu, S., Liu, S., Li, K., \& Ren, T. 2009. Soil organic carbon and physical quality as influenced by long-term application of residue and fertilizer in the north China Plain. Australian journal of soil research, 47, 585-591.

[11] Duiker, S. W., \& Lal R. 1999. Crop residue and tillage effects on carbon sequestration in a Luvisol in central Ohio. Soil Tillage Res, 52, 73-81.

[12] Ghimire, R., Adhikari, K. R., Chen, Z. S., Shah, S. C. \& Dahal, K. R. 2012. Soil organic carbon sequestration as affected by tillage, crop residue, and nitrogen application in rice-wheat rotation system. Paddy Water Environ, 10, 95-102.

[13] Ghosh, S., Wilson, B., Ghoshal, S, K., Senapati, N., and Mandal, B. 2010. Management of soil quality and carbon sequestration with long-term application of organic amendments. $19^{\text {th }}$ World Congress of Soil Science, Soil Solutions for a Changing World. 16 August, 2010, Australia.

[14] Govaerts, B., Verhulst, N., Castellanos-Navarrete, A., Sayre, K. D., Dixon, J. \& Dendooven, L. 2009. Conservation agriculture and soil carbon sequestration: Between myth and farmer reality. Critical Reviews in Plant Sciences, 28, 97-122.
[15] Grace, P. R., Jain, M. C., Harrington, L., \& Robertson, G. P. 2003. Long-Term Sustainability of the Tropical and Subtropical RiceWheat System: An Environmental Perspective. In: Improving the Productivity and Sustainability of Rice-Wheat System: Issue and Impacts (p.65). ASA Special Publication.

[16] Gupta, R. \& Seth, A. 2007. A review of resource conserving technologies for sustainable management of the rice-wheat cropping systems of Indo-Gangetic plains (IGP). Crop Protection, 26, 436-447.

[17] Jat, M. L., Singh, R. G., Saharawat, Y. S., Gathala, M. K., Kumar, V., Sidhu, H.S., \& Gupta, R. 2009. Innovations through conservation agriculture: progress and propects of participatory approach in the indo-gangetic plains. Lead papers, $4^{\text {th }}$ world congress on conservation agriculture (pp. 60-64). 4-7 February 2009, New Delhi, India.

[18] Kaisi, A. M. \& Yin, X. 2005. Tillage and crop residue effects on soil carbon and carbon dioxide emission in corn-soybean Rotations. J. Environ. Qual, 34, 437-445.

[19] Khanal, N. P., Maharjan, K. L. \& Dangol, D. R. 2012. Soil conservation practices for sustainability of rice-wheat system in Nepal: A Review. Journal of International Development and Cooperation, 18 (4), 11-20.

[20] Ladha,. J. K., Fischer, K. S., Hossain, M., Hobbs, P. R. \& Hardy, B. 2000. Improving the productivity and sustainability of ricewheat systems of the Indo-gangetic plains: a synthesis of NARSIRRI partnership research. Discussion Paper No. 40.

[21] Lumpkin, T. A. \& Sayre K. 2009. Enhancing resource productivity and efficiency through conservation agriculture. Lead papers, $4^{\text {th }}$ world congress on conservation agriculture (pp. 3-9). 4-7 February 2009, New Delhi, India.

[22] Mandal, K. G., Mishra, A. K., Hati, K. M., Bandyopadhyay, K. K., Ghosh, P. K. \& Mohanty, M. 2004. Rice residue management options and effects on soil properties and crop productivity. Food, Agriculture and Environment, 2 (1), 224-231.

[23] Ram, H., Singh, Y., J. Timsina, Humphreys, E., Dhillon, S. S., Kumar, K. and Kler, D. S. 2005. Performance of upland crops on raised beds on Northwestern India. In: C.H. Roth, R.A. Fischer and C.A. Meisner (eds). Evaluation and performance of permanent raised bed cropping system in Asia, Australia and Mexico (pp. 41-58). ACIAR Proceeding No. 121.

[24] Rattan, R. K. \& Datta, S. P. 2011. Carbon sequestration and agricultural production in India. In: A. R. Sharma and U. K. Behera (eds). Resource conserving techniques in crop production (pp. 155-165). Scientific publishers, India.

[25] Regmi, A. P., Ladha J. K., Pathak, H., Pasuquin, E., Bueno, C., Dawe, D., Hobbs, P. R., Joshy, D., Maskey, S. L. \& Pandey, S. P. 2003. Yield and soil fertility trends in a 20 -year rice-rice-wheat experiment. Better crops international, 17(2), 30-31.

[26] Shah, P. 2008. Effect of long-term tillage, mulch and time of nitrogen application on weeds and yield of wheat (Triticum aestivum). Unpublished M. S. Thesis, Institute of Agriculture and Animal Science (IAAS), Rampur, Chitwan, Nepal.

[27] Sharma, R. K. 2011. Resource conserving technologies for sustainability of rice-wheat system. In: A. R. Sharma and U. K. Behera (eds). Resource conserving techniques in crop production. (pp. 61-73).Scientific publishers, India.

[28] Singh, K.K. \& Sharma, S.K. 2005. Conservation tillage and crop residue management in rice-wheat cropping system. In: I.P. Abrol, R.K. Gupta and R.K. Malik (eds). Conservation agriculture-status and prospects. (pp. 23-32).Centre for Advancement of Sustainable Agriculture, New Delhi.

[29] Singh, Y. 2011. Crop residue management for improving soil and crop productivity. In: A. R. Sharma and U. K. Behera (eds). Resource conserving techniques in crop production (pp. 166-189). Scientific publishers, India.

[30] Tripathi, J. 2010. Evaluation and promotion of resource conservation technologies in low land rice-wheat ecosystem. Agro. J. of Nepal, 1, 28-39.

[31] Venkateswarlu, B., Sharma, K. L. \& Prasad, J.V.N.S. 2009. Conservation agriculture: constraints, issues and opportunities in rainfed areas. Lead papers, $4^{\text {th }}$ world congress on conservation agriculture (pp. 80-84). 4-7 February 2009, New Delhi, India.

[32] Watson, C. A., Atkinson, D., Gosling, P., Jackson, L. R. \& Rayns, F. W. 2002. Managing soil fertility in organic farming systems. Soil Use and Management, 18, 239-247. 